\title{
Critical Perspective and Reconstruction Governance Organization Management Zakat In Indonesia
}

\author{
Cahyo Budi Santoso \\ University lecturer, Riau Kepulauan, Batam, Indonesia \\ Mohammad Nizarul Alim \\ University lecturer, Trunojoyo, Madura, Indonesia \\ Slamet Riyadi \\ University lecturer, August 17, 1945, Surabaya, Indonesia
}

\begin{abstract}
BAZNAS ss an official institution and given the authority in the management of zakat in Indonesia, then in order to accountability the management of zakat needs to be based on a variety of regulatory and operational strengthening. Organization Manager Zakat is the organization that manages the funds of the community i.e. the funds to charity. OPZ has the role of intermediation zakat fund convened to the community i.e. muszaki and transmitted and harnessed to the community mustahik. For a regulation related to the management of zakat be very important. This research is qualitative one, with descriptive design. While, data taking was done by observations and deeply interviews. This study used qualitative research method where the data were collected by observation and in-depth interviews. The data collection was done in natural settings. Primary data were collected through participant observation towards staff who received allowances, in-depth interviews and documentation (audio recording). Respondents in this study consist of four informants. Important findings in this research are: (1) Transparent on BAZNAS marked information in a timely, adequate, accessible, business objectives, strategies, financial condition, the company arrangement and compensation of Executive Board, the controlling shareholder, internal control and supervision system, the principle of openness and policy writing and proportionate. (2) Accountability at BAZNAS marked the details of duties and responsibility of the organ and all employees clear, aligned with the vision, mission, values and strategy BAZNAS. employees were able to on duty, responsibility, and its role in the implementation of GCG Principles, tasks and authority, ethical behaviour and employee agreed. (3) Responsibility on BAZNAS in mark awareness of responsible offices attached, awareness of the existence of social responsibility and working in a professional manner and uphold ethics and code of conduct of the organization.(4) Independence at BAZNAS in mark awareness being the responsibility of the appropriate Office attached to, awareness of social responsibility and professional ethics, and code of ethics of the Organization and maintaining a healthy work environment and is conducive and (5) Fairness in BAZNAS in the mark system of payment of Zakah are easy and simple on-line through the medium, the amount of the payment of zakat muzakki is equal to the amount agreed upon in advance and accept criticism and suggestions from other parties.
\end{abstract}

Key Words: Transparent, Accountability Responsibility, Independence and Fairness

\section{INTRODUCTION}

Zakat funds have the potential to be developed economically. In the last decade, zakat has developedrapidly when viewed from its growth. However, the growth of zakat is still very far away with the true potential of zakat. The results of some studies mention potential zakat Indonesia vary between 12.7 trillion and Rp 286 billion (Outlook Zakat Indonesia, 2017 in Santoso, 2017). The problems in Indonesia Zakah can be caused by several factors cause not 
optimal management of zakat in Indonesia are: 1) the ineffectiveness of the organization collecting zakat; 2) high administrative costs to manage zakat; 3) information about the importance of paying zakat which is not effective; and 4) distrust the muzakki (Zakah payer) against the Organization managers zakat (OPZ) (Hafidhudin; 2007, Laela; 2010).

The number of OPZ so much (545 units), plus the complete regulation will no doubt more and gives hope that the management of zakat in Indonesia is getting better and increasingly realize the vision that is making people become prosperous. There are three pillars that need optimized manifest prosperity of Ummah, the nation and the State, namely 1) the empowerment potential of zakat; 2) Empowerment potential of endowments; and 3) empowerment of the mosque (Adib Machrus et al, 2013). However, in reality there is quite the weaknesses. This weakness is compounded by the more selfish with the institutional managers felt that each authority got OPZ/authority to manage the funds of Ummah who own to collected. Zakat in Alim (2015) provides an opportunity to take advantage of zakat for purposes of productive and suggests that institutions amil zakat zakat funds productively harness (Alim, 2015).

This has an impact on Spacey will be coordination, cooperation and a more fatal again is important data for the analysis can be less accountable. This is the weakness of the management of the zakat or difficult in Congregation (Sudewo, 2012). This phenomenon shows that Organizational governance Manager Zakat (amil governance) in Indonesia was still weak. The governance of the Organization is a set of systems, processes, customs, policies, and rules governing the relationship between the different stakeholders so that the objectives of the Organization are achieved (Abdul Haris, 2005)

The governance of non profit organization emphasizing the relationship between the interests of the Government in charge of regulating the country's problems with the interests of the community, entrepreneurs, investors, and others. When the relationship between the parties is not good stakeholders interests can lead to difficult to achieve the goals of the organization. OPZ must be managed properly so that the objectives of the organization can be achieved, so that the management of zakat, not simply how to muster and funneling the funds to charity, but also concerns the relationships that organize between different stakeholders, i.e. muzaki, amil, mustahik, Government, corporate, community and more.

The governance of the Organization was strongly influenced by objective, legal, regulatory, ethical codes, statutes, treaties, muzaki, mustahik, Government, communities and other stakeholders. The governance of the Organization was formed through a culture of organizational culture, values, systems, a wide range of processes, policies and organizational structur, with the purpose to achieve the purpose of the management of zakat, namely: 1) improve effectiveness and service efficiency in the management of zakat; and 2) increase the benefits of zakat for realizing the welfare of society and poverty reduction.

Although the legal basis the management of zakat, on one side to encourage organizational Manager popping up zakat (Karim and Syarief, 2008), but on the other hand there are still many shortcomings in the management of social function and a prime target of worship Zakat is not optimally achieved (Faizal 2011, Gusfahmi 2008, 2009 Beik, Mintarti et al 2009). Some of the weakness that is committed and less cooperation between the entire stakeholder zakat (Beik 2009), empowerment of zakat have not reached expected goal (Mintarti et al 2009), zakat have not allowed as a deduction of tax (Gusfahmi, 2008). Zakat in Alim (2015) provides 
an opportunity to take advantage of zakat for purposes of productive and suggests that institutions amil zakat zakat funds productively harness

Zakat plays an important role in poverty reduction. The important role of zakat can be realized when there is a change of paradigm in the management concept of zakat, zakat management concept should Change the totality and thorough (Miftah 2008). According to Laela (2010) the existence of independent auditor's report influenced the efficiency of OPZ. This shows that stakeholders strongly influenced the success in the management of zakat.

The birth of UUPZ which gives the authority on BAZNAS to provide recommendations upon the establishment of a LAZ, need attention. A BAZNAS the level of acceptance of the Fund is still receiving funds under the LAZ, may give recommendations to LAZ that acceptance of funding is higher than BAZNAS? This phenomenon demonstrates the still weak corporate governance of zakat in Indonesia. Therefore, the need for an in-depth and critical study of the implementation of the management of zakat which exists as long as it can be arranged so that a construction of the concept of charity governance for the Organization Indonesia Zakah in Manager.

\section{Good Corporate Governance (GCG)}

\section{LITERATURE REVIEW}

Within the General guidelines of GCG Indonesia drawn up by the National Policy Committee on Governance in 2006 mentions that there are 5 (five) the principles of GCG, namely:

1. Transparency could be interpreted as information disclosure, both in the decisionmaking process and disclose information material and relevant regarding the entities (Gerald Crawford, 2010) the essence of the principle of transparency is increasing openness of the entity's performance regularly and on time and right (Tangkilisan, 2003:100).

2. Responsibilities of each component of the Organization in line with the vision, mission, targets and strategies entitas. Each component organization competency in accordance with the respective level (Sutedi, 2011:88). Accountability is a clarity function, structure, systems and accountability organs entitas until administrating organization execution effective (Ramdhani, 2010)

3. Accountability of enterprise have the responsibility to comply with the law and the standards or regulations occur, including responds to the range where entitas are (Tangkilisan, 2003:100). Organizational responsibility is appropriate (non-compliant) against the principles of a healthy Corporation as well as the rules of incurred. Rules that occur here including those related to the problem leases, contact industrial, protection of the environment, health or safety of work, employment and competition standart Hale (Ramdhani, 2010).

4. Independence is an important principle in the implementation of GCG. Independence or self-reliance is a situation where a company is managed professionally without a conflict of interest and influence or pressure from any party that is contrary to the applicable legislation and the principles a healthy Corporation (Tangkilisan, 2003:100).

5. Fairness Naturalness is justice and equality in fulfilling the stakeholders ' rights arising under the Treaty and the regulations in force. In a simple reasonableness in fulfilling the stakeholder's rights arising under the Treaty and the regulations of the applicable legislation. Fairness is expected to make the whole company assets are managed properly and carefully, so it appears the protection of shareholders interests honestly and fairly (Tangkilisan, 2003:102).

Bank Indonesia also supports and requires the implementation of GCG or commercial banks and Islamic Syariah Business Unit who poured in circular letter of Bank Indonesia No. BI SE. 
No. 12/13/DPbs circulars to all Syariah commercial banks and Syariah Business Unit in Indonesia.

1. The implementation of GCG in the Sharia banking industry should be based on five basic principles are transparency, accountability, responsibility, professional and fairness.

2. In the implementation of GCG, banks need to do checks and balances, avoid conflicts of interest in the performance of duties as well as increasing protection for the interests of the stakeholders especially the owner of customer funds and holders of a minority stake.

3. In an effort to repair and improve the quality of GCG implementation, banks are required periodically do a self assessment comprehensively against the adequacy of implementation of GCG. If there are still deficiencies in its implementation, the Bank immediately set the necessary improvement measures.

4. As one form of implementation of the principle of transparency (transparency), banks are required to submit a report to stakeholders GCG Implementation. The report in question is required to improve the understanding of stakeholders and encourages stakeholders do checks and balances

\section{Accounting of Theory}

Agency in the theory of Agency, an agency relationship arises when one or more people employs another person to provide a service and then delegate authority decision-making to the agent. Thus the Agency theory emphasizes the importance of the surrender of the company's operations from the owner to other parties who have the ability to manage the company with the better. The relationship between the principal with the agent can lead to an imbalance condition information because the agent is in a position which has much more information about the company than with the principal.

\section{GCG in an Islamic perspective}

Islam has the concepts and values that are far more complete and more comprehensive in avoiding the presence of illegal practices, fraud and dishonest in accepting the mandate. One of the principle which is derived from the value of unity is the principle of Justice. Islamic teachings encourage his people to be fair in any way, either in the matter of aqidah, syariah and akhlaq. As Word of Her in surah Al Maidah verse 8:Meant "Hai people believe, shall not be those who always uphold (the truth) because God bear witness with justice, and do not let the your hatred against a race, prompting the for you happened is unfair. Occur, because the fair adil closer to God-consciousness and conscious of Allah. Surely Allah is aware of what we do. " (At Taubah: 8)

One of the principles in the implementation of GCG is fairness. Fairness presents the management entities are equitable for all parties. If associated with Sharia, then Justice should include aspects of the spiritual and the material. Then the meaning of fair use can be expanded to every principle contained in GCG as well as other values may appear over the implementation of Justice

\section{Data Source}

\section{RESEARCH METHODS}

Data required in this research are data collected from employees and management using indepth interviews and observations, either directly or indirectly to each informant. And no less important is that data could be made available, both in the community and from the results of previous studies either contained in journals and special reports. The primary data source is 
the information selected intentionally based on BAZNAS RI and LAZNAS BMH documents and observations. There are four informants in this study.

\section{Qualitative Method}

This study used qualitative method, namely using participant observation method and interviews used regularly in the social sciences. According to Sugiyono (2005), the qualitative method is a method used by researchers in the natural objects, where the researcher is a key instrument, in which data are collected by triangulation. Data analysis is indicative only, and the results of the research more places an emphasis on meaning rather than the generalization. Please note that qualitative method does not reject the numbers and use statistical techniques for data presentation and analysis.

Qualitative research also represents a research procedure that produces descriptive data in the form of speech or written words and behaviors that can be observed from the people themselves. This research will directly show the background of individuals overall.

\section{ANALYSIS AND DISCUSSION}

Based on the research results obtained $d$ that there are 4 informants who made data source, obtained some information as well as based on the gender of the study was obtained from the informant-sex male as much as 3 informants and a There is 1 female genital informants and to educational status, suitably S3 informant as much 1 informant, the informant as much as 1, S2 and suitably high school, as much as two informants.

1. Based on the sex of the informant's description based on gender in the study was obtained by that of 4 consists of the informant informant-sex male as much as 3 informants and there is 1 female-sex informant.

2. On the basis of Long Working duration of the task based on the informant working on this research obtained that there are 1 the informant worked for less than 5 years, there were two informants who work between 6-10 years.

3. On the basis of Education And to educational status, the informant berijazh S3 as much as 1 informant, the informant as much as 1, S2 and suitably HIGH SCHOOL as much as two informants.

\section{Research Findings}

Research findings based on the previous description, it can be noted that in this study produced some findings that can be described briefly as follows:

1. The application of the concept of the GCG on transparent as information disclosure, both in the decision-making process and in relevant materials and disclose information concerning the entity, which is characterized by a charity Manager) has been providing information in a timely, adequate, clear, accurate and can be compared as well as accessible to people (Zakah payer) in accordance with its rights, b) reveal information which includes the vision, mission, objectives, strategies, financial condition, the company's order and compensation of the Executive Board, the controlling shareholder, the system of supervision and internal controls, as well as the implementation of GCG system level, c) revealed a principle of openness that does not reduce the obligation to comply with the confidentiality BAZNAS in accordance with the regulations, the secret Office, and personal rights and d) Applying a policy of BAZNAS in writing and proportionately communicated to stakeholders.

2. Application of transparent on BAZNAS marked with a) information in a timely, adequate, clear, accurate and can be compared as well as easily accessible to the people. b). information that includes a vision, mission, objectives, strategies, financial condition, the company arrangement and compensation of Executive Board, the controlling 
shareholder, internal control and supervision system, c). the principle of openness that does not reduce the obligation to meet the conditions of confidentiality. d). Apply the policy in writing and communicated to the proportionately stakeholder.

3. The application of accountability at BAZNAS duitandai a). details of the duties and responsibilities of the respective organs and all employees are clear, and aligned with the vision, mission, values and strategy BAZNAS. b). All organs and employees have the ability to match the duty, responsibility, and its role in the implementation of GCG. c). Perform the duties and authority, every employee must adhere to ethics and conduct: agreed.

4. Application of responsibility on BAZBAS on the mark with a). have awareness for responsible position attached. b). Awareness of the existence of social responsibility. c). work in a professional manner and uphold ethics and code of conduct of the organization. .d). Have kept a healthy working environment and is conducive

5. Application of independence at BAZNAS on the mark with a). awareness Has to be tangungjawab as one of the kosekuensi attached to the Office. b). Have an awareness of social responsibility. c). work in a professional manner and uphold ethics and code of conduct of the organization. d). Maintain a healthy working environment and is conducive.

\section{Theoretical Implications}

Perspective of the development of theory, this research can be categorized as a development of the theory of agency theory About governance, the business Zakat collection, distribution, utilization and reporting of zakat for the sake of the benefit of the people. The results of this research show that the collection, distribution, utilization and reporting of zakat, already implemented although there still needs to be reviewed and corrected, with the regulations so that the governance of Zakat for the better again. Also need to add the new rules in the form of presidential instruction about the collection, distribution, utilization and reporting of zakat.

The results of this research with the research results Faisal (2011) who found that the classic or modern Islamic world has published a wide range of legislation and running various zakat management pattern in order to alleviate poverty. Similarly in Indonesia the main purpose of Zakan governance in BAZNAS is to maximize the participation of the Organization in supporting the charity program manager along with utilization of zakat. Adiwarman et al (2008) which suggests that the euphoria of reform, the phenomenon of the booming Islamic finance industry until the publication of the ACT on the management of Zakat has succeeded in encouraging the development of LAZ toward more professional, transparent, accountability and responsibility.

This indicates that management of zakat more advanced and evolved over the development of other Islamic instruments. Gusfahmi research results (2008) about Reconstruction practice of Zakat and tax to tackle Poverty are: (a) the definition of the tax in the law No. 28 year 2007 has yet to mention explicitly the obligation it is the command of Allah; (b) the object of taxation in Indonesia has not fully attributable to the excess possessions and productive. Irfan Syauqi Beik (2009), in the analysis of the role of Zakat in reducing Poverty found that: (a) the Charity is able to reduce the number of poor families; (b) the Zakat is able to reduce the poverty gap and income gap; (c) the need for a strong commitment and cooperation between the entire stakeholders both Government representathive, zakat and the institutions or bodies of the community as a whole in realizing a sustainable development charity 


\section{SUMMARY}

Result of analysis and discussion can be summarized as follows:

1. Transparent on BAZNAS marked information in a timely, adequate, accessible, business objectives, strategies, financial condition, the company arrangement and compensation of Executive Board, the controlling shareholder, internal control and supervision system, the principle of openness and policy writing and proportionate.

2. Accountability at BAZNAS marked the details of duties and responsibility of the organ and all employees clear, aligned with the vision, mission, values and strategy BAZNAS. employees were able to on duty, responsibility, and its role in the implementation of GCG Principles, tasks and authority, ethical behaviour and employee agreed.

3. Responsibility on BAZNAS in mark awareness of responsible offices attached, awareness of the existence of social responsibility and working in a professional manner and uphold ethics and code of conduct of the organization.

4. Independence at BAZNAS in mark awareness being the responsibility of the appropriate Office attached to, awareness of social responsibility and professional ethics, and code of ethics of the Organization and maintaining a healthy work environment and is conducive.

5. Fairness in BAZNAS in the mark system of payment of Zakah are easy and simple online through the medium, the amount of the payment of zakat muzakki is equal to the amount agreed upon in advance and accept criticism and suggestions from other parties.

\section{LIMITATIONS}

Based on the conclusions and findings of the research, there are some suggestions that can give researchers for the benefit of the management of Zakat, science, as well as further research presented some suggestions as follows:

1. To Governments (BAZNAS)

It is recommended to the BAZNAS in regards to the collection, distribution, utilization and reporting of zakat, there still needs to be reviewed and improved, particularly in terms of Act No. 23, 2011 on BAZNAS needs to be supplemented, corrected with the regulations so that the governance of Zakat for the better again.

2. To the development of Research

Findings obtained in this research can be input and consideration to research the next so that the development of science in particular of the science of human resource development, in the concept of Zakat grow in accordance with the development of the times and the times.

\section{BIBLIOGRAPHY}

Alim, M..N. 2015. Utilization and Accounting of Zakat for Productive Purposes in Indonesia: A Review. Procedia Social and Behavioral Sciences 211: 232 - 236.

A.A. Miftah. 2008. Renewal of Zakat For poverty reduction in Indonesia. Innovatio, Volume 7, number 14, JulyDecember 2008, 423-439

Abdul Haris. 2005. 7 Pillars the company Excels. Jakarta: Gramedia Pustaka Utama.

Abdullah, M. 2014. Management and Employee performance evaluation. Yogyakarta: Aswaja Name.

Adib Machrus dkk. 2013. The organization's Guide Maintainer Zakat. Directorate General Guidance Of The Islamic Community. The Directorate Of Enforcement Of Zakat.

Faisal, 2011. The history of the management of Zakat in the Muslim world and Indonesia (Investigative Theory Approach - the history of Charles Pierce and Lieven Boeven Truth Deficit). Analysis, Volume XI, number 2, January 2011 
Gusfahmi, 2008. Reconstruction practice of Zakat and tax to tackle poverty. Journal of thoughts and ideas, Volume 1 Number 4, August 2008

Hafidhuddin, Didin. 2007. In order to Gain blessings and Treasures (movement to cultivate the religious obligatory, Infaq, Alms, Endowments), Jakarta: Gema Insani.

Irfan Syauqi Beik, 2009. Analysis of the role of Zakat in reducing poverty: a case study of Dompet Dhuafa Republika. Journal of thoughts and ideas, Volume 2, Thani, Jumada 1430H.

Santoso, Cahyo Budi, 2017. Zakah Organization as the Fourth Sector. International. Journal of Economics and Finance; Vol. 9, No. 12. Canadian Center of Science and Education.

Tangkilisan, Hessel. 2003. The implementation of public policy. Yogyakarta: Lukman Offset 2002. The decision of the Minister of State-owned enterprises number: Kep/117/M-MBU/2002 of 1 August 2002 On Good Corporate Governance. Jakarta

2002. Rules State Minister of State-owned enterprises number: PER-01/MBU/2011. On August 1, 2002 On the implementation of good Corporate Governance (Good Corporate Governance) State-owned enterprises. Jakarta. 2005. Government Regulation number 23 year 2005 About the Agency's Financial management of the public service. Jakarta. 